\title{
Clinical characteristics of small cell carcinoma of the breast
}

\author{
NORIAKI SADANAGA ${ }^{1,2}$, SATOKO OKADA ${ }^{1}$, SATOKO SHIOTANI ${ }^{1}$, MASARU MORITA $^{1}$, YOSHIHIRO KAKEJI ${ }^{1}$, \\ KAORU KITAMURA ${ }^{2}$, SADAFUMI TAMIYA ${ }^{3}$, KEIZO SUGIMACHI ${ }^{2}$ and YOSHIHIKO MAEHARA ${ }^{1}$
}

Departments of ${ }^{1}$ Surgery and Science, and ${ }^{3}$ Anatomic Pathology, Pathological Sciences, Graduate School of Medical

Sciences, Kyushu University; ${ }^{2}$ Department of Surgery, Kyushu Central Hospital, Fukuoka, Japan

Received September 21, 2007; Accepted November 20, 2007

\begin{abstract}
Primary small cell carcinoma of the breast is a rare tumor of which less than 40 cases have been reported in the literature. Because of its rarity, its biological and clinical characteristics are still not fully understood and, to date, no standard therapy has been developed. Here, we present a case and a review of the literature regarding this cancer, focusing on clinicopathological findings and treatment. Primary small cell carcinoma of the breast differs from more common types of breast cancer in its biological features. It is anticipated that an improved understanding of the clinical characteristics of this tumor will result in the development of new therapeutic modalities, which would improve its prognosis.
\end{abstract}

\section{Introduction}

The extrapulmonary occurrence of small cell carcinoma was reported only recently (1). Primary small cell carcinoma of the breast was first reported by Wade et al in 1983 (2). An uncommon neoplasm, less than 40 cases of it have been reported in the literature, and neither its characteristics nor a standard course of therapy have been clearly defined (3-21). In the present report, we describe a case we treated and review and discuss the literature on this tumor, with a focus on its clinical characteristics and treatment.

\section{Case report}

A 33-year-old premenopausal Japanese woman presented with a right breast lump. Clinical examination revealed two firm mobile masses $(4.0 \times 3.5 \mathrm{~cm}$ and $2.5 \times 2.0 \mathrm{~cm})$ in the upper outer quadrant of the right breast. A contrast-enhanced MRI of her breast showed several enhanced masses in the right upper outer and central quadrants (Fig. 1). A core needle biopsy was

Correspondence to: Dr Noriaki Sadanaga, Department of Surgery and Science, Graduate School of Medical Sciences, Kyushu University, Fukuoka 812-8582, Japan

E-mail: nsadanag@surg2.med.kyushu-u.ac.jp

Key words: breast cancer, small cell carcinoma, clinicopathological findings, treatment performed and the tumor was diagnosed as an invasive carcinoma. A right total mastectomy with axillary lymph nodes dissection (levels I-III) was performed. The pathological diagnosis was of small cell carcinoma. The tumor was composed of fairly uniform small dark cells disposed in nests and trabecular patterns, separated by bands of fibrous tissue. The cells had a high nucleocytoplasmic ratio, small hyperchromatic nuclei with inconspicuous nucleoli, scanty cytoplasm and poorly-defined cytoplasmic borders (Fig. 2). An immunohistochemical study showed that both estrogen (ER) and progesterone receptors (PgR) were negative, as was HER2 expression. Neuron-specific enolase (NSE) gave a positive reaction, and chromogranin and synaptophysin a negative one. No lymph node metastasis was found $(0 / 41)$. The patient received four courses of epirubicin $\left(60 \mathrm{mg} / \mathrm{m}^{2}\right)$ and cyclophosphamide $\left(600 \mathrm{mg} / \mathrm{m}^{2}\right)$ as postoperative adjuvant chemotherapy. Six months after surgery, MRI and an enhanced CT scan showed right parasternal lymph node recurrence $(1.5 \times 1.0 \mathrm{~cm})$. The patient was treated with radiation $(50 \mathrm{~Gy})$ to the right chest wall, including the parasternal lymph nodes. The swollen lymph nodes decreased in size after radiation therapy and the patient is currently alive at 60 months after surgery.

\section{Discussion}

Primary small cell carcinoma of the breast is a rare tumor. A review of its clinicopathological characteristics in previous reports is summarized in Table I (2-21). Women were affected in all cases but one (3), and the reported age of incidence was 33-75 years (average, 54.7). Tumor size ranged from 1.0 to $18 \mathrm{~cm}$ (mean, $4.4 \mathrm{~cm}$ ). Although the frequency of vascular invasion and lymph node metastasis was, respectively, about 30 and $40 \%$ in the common phenotype of invasive ductal carcinoma, 71\% (10/14) of patients had vascular invasion and $59 \%$ (19/32) axillary lymph node metastasis. Intraductal lesions were seen in $61 \%(19 / 31)$ of the tumors. The presence of an in situ component was a useful, but not indispensable, discovery for the diagnosis of primary mammary tumors $(4,10)$.

Table II summarizes our review of the immunohistochemical studies of previous reports. Regarding hormonal receptor findings, the positive ratio of ER was $27 \%(9 / 33)$ and of PgR 33\% (9/27). Her2 overexpression was found in only $4.8 \%(1 / 21)$ of the reported cases. In general, the frequency of ER, PgR and HER2 overexpression was, 

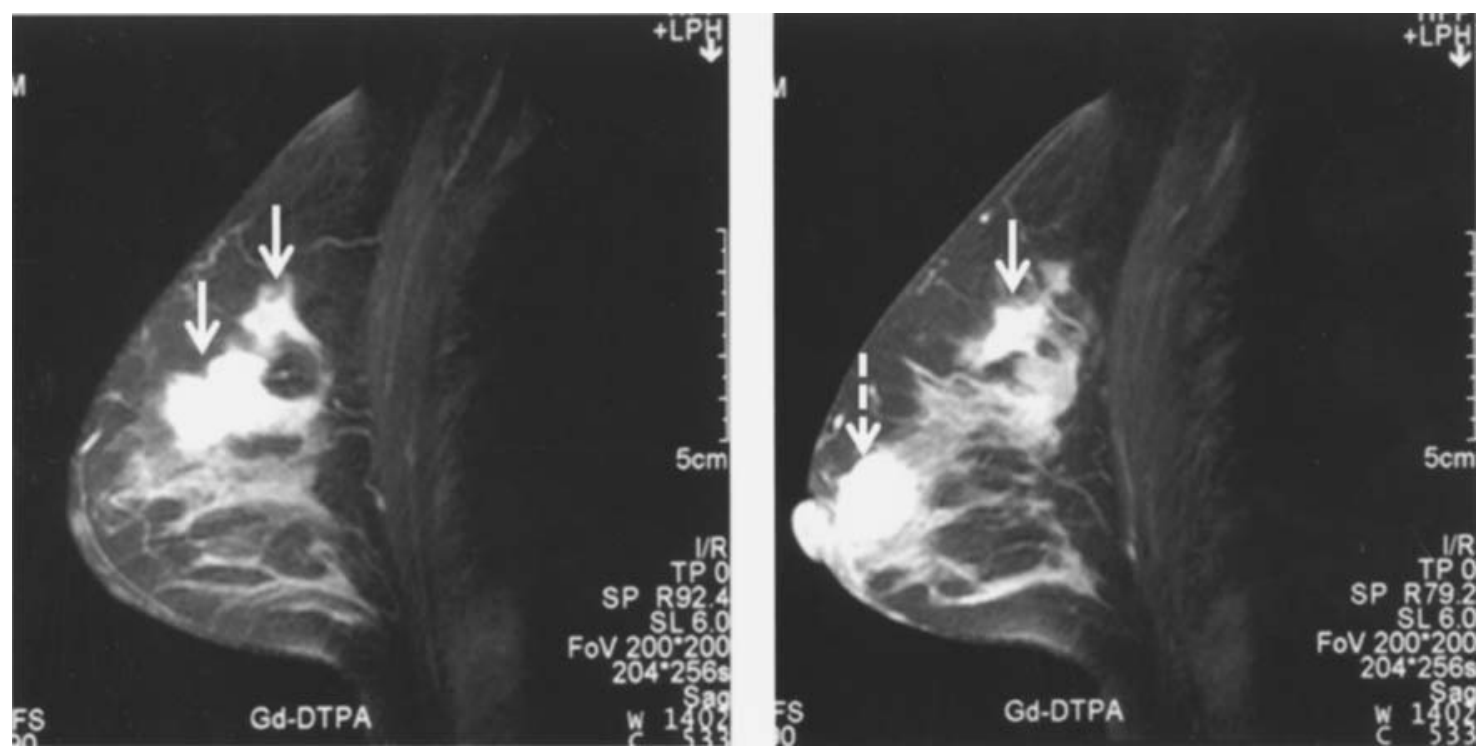

Figure 1. Contrast-enhanced MRI of the patient's breast. There were several enhanced masses in the right upper outer (solid arrow) and central (dotted arrow) quadrants.
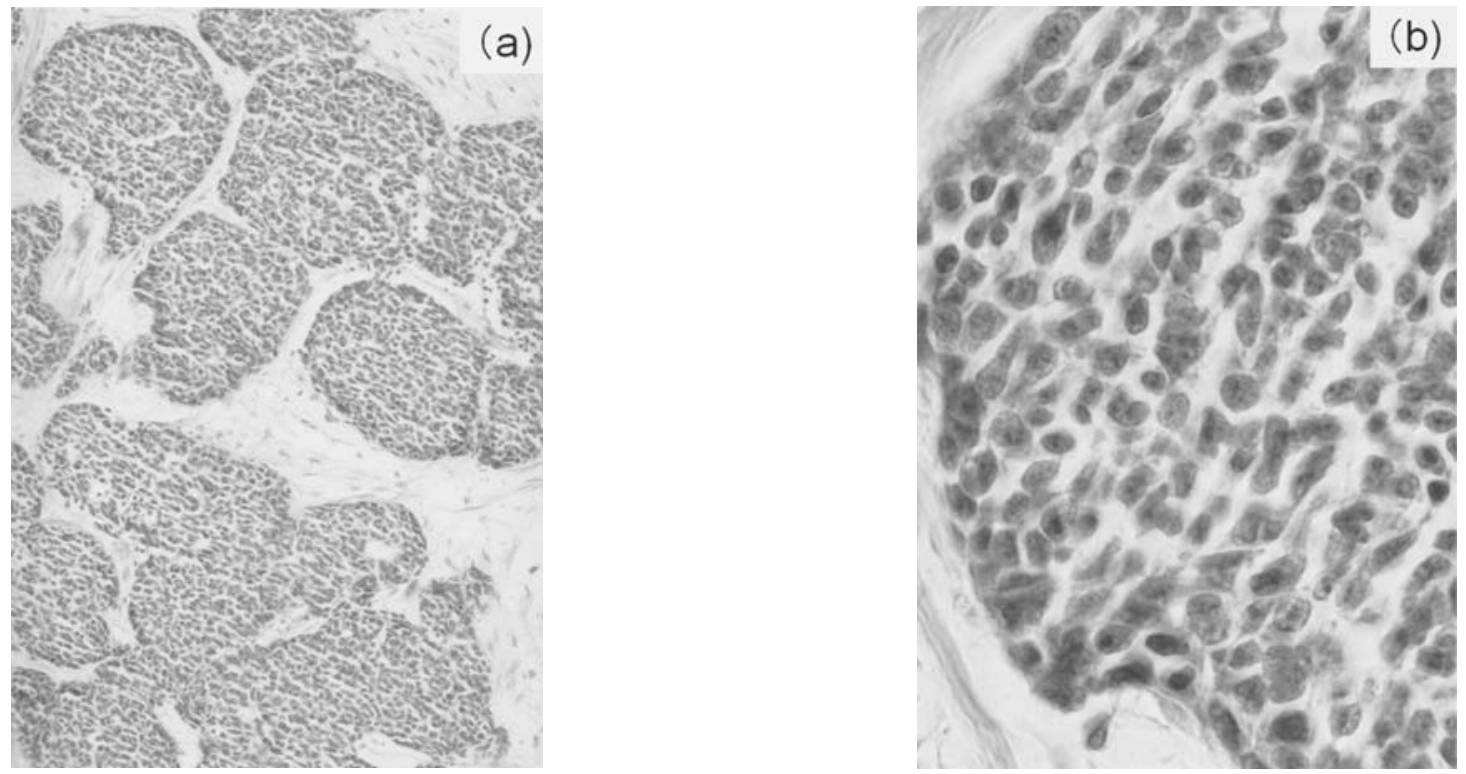

Figure 2. Small cell carcinoma of the breast. (a) Fairly uniform small dark cells disposed in nests and trabecular patterns separated by bands of fibrous tissue (x40). (b) Tumor cells have a high nucleocytoplasmic ratio, small hyperchromatic nuclei with inconspicuous nucleoli, scanty cytoplasm, and poorly defined cytoplasmic borders (x100).

Table I. Summary of clinicopathological findings in previously reported ${ }^{1}$ primary small cell carcinoma of the breast.

\begin{tabular}{lc}
\hline Clinicopathological characteristics & Value \\
\hline Gender (male/female) & $1 / 36$ \\
Mean age (years) & $54.7 \pm 10.3$ \\
Mean size (cm) & $4.4 \pm 3.7$ \\
No./total no. lymph node metastasis (\%) & $19 / 32(59.3)$ \\
No./total no. vascular invasion $(\%)$ & $10 / 14(71.4)$ \\
No./total no. intraductal lesion $(\%)$ & $19 / 31(61.3)$ \\
\hline
\end{tabular}

${ }^{1}$ References 2-21.
Table II. Summary of immunohistochemical studies in previously reported ${ }^{1}$ primary small cell carcinoma of the breast.

\begin{tabular}{lc}
\hline Immunohistochemical staining & No./total no. $(\%)$ \\
\hline ER & $9 / 33(27.3)$ \\
PgR & $9 / 27(33.3)$ \\
HER2 & $1 / 21(4.8)$ \\
NSE & $30 / 34(88.2)$ \\
Chromogranin & $17 / 31(54.8)$ \\
Synaptophysin & $18 / 30(60.0)$ \\
\hline
\end{tabular}

${ }^{1}$ References 2-21. 
Table III. Summary of treatment and prognosis in previously reported primary small cell carcinoma of the breast.

\begin{tabular}{|c|c|c|c|c|c|c|c|}
\hline Case & Author/(Refs.) & Year & TNM & Primary treatment & Site of recurrence & Additional treatment & Prognosis \\
\hline 1 & Wade et al (2) & 1983 & T4N1M1 & $\mathrm{Bt} / \mathrm{Ch}(\mathrm{CDV})$ & $\begin{array}{l}\text { Axillar LN, } \\
\text { liver bone }\end{array}$ & VP-16, R & DOD 9M \\
\hline 2 & Jundt et al (3) & 1984 & TxN1MX & $\mathrm{R} / \mathrm{Ch}$ & $\begin{array}{c}\text { Axillar LN, hepatic } \\
\text { porta } \mathrm{LN}, \text { bone }\end{array}$ & $\mathrm{R} / \mathrm{Ch}$ & DOD 14M \\
\hline 3 & Pappoti et al (4) & 1992 & T1N0M0 & $\mathrm{Bt}$ & - & - & NED 44M \\
\hline 4 & Pappoti et al (4) & 1992 & $\mathrm{~T} 2 \mathrm{~N} 1 \mathrm{M} 0$ & $\mathrm{Bt} / \mathrm{R}$ & Several organs & - & DOD $15 \mathrm{M}$ \\
\hline 5 & Pappoti et al (4) & 1992 & $\mathrm{~T} 2 \mathrm{~N} 1 \mathrm{M} 0$ & $\mathrm{Bt} / \mathrm{Ch}$ (streptozotocin) & $\begin{array}{l}\text { Liver, brain } \\
\text { skin, lung }\end{array}$ & Ch (CMF)/R40Gy & DOD 14M \\
\hline 6 & Pappoti et al (4) & 1992 & T3N1MX & Bt/tamoxifen & - & - & DOC 9M \\
\hline 7 & Francois et al (5) & 1995 & T2N0M0 & $\mathrm{Bt} / \mathrm{R}$ & $\begin{array}{l}\text { Subclavicular, } \\
\text { inner mammary } \\
\text { LN, lung }\end{array}$ & $\begin{array}{c}\text { Ch (doxorubicin, } \\
\text { cyclophosphamide, } \\
\text { VP-16) }\end{array}$ & DOC $21 \mathrm{M}$ \\
\hline 8 & Chua et al (6) & 1997 & T1NXM0 & $\mathrm{Bp}$ & - & - & Not described \\
\hline 9 & $\begin{array}{l}\text { Fukunaga and } \\
\text { Ushigome (7) }\end{array}$ & 1998 & T3N1M0 & $\mathrm{Bt}$ & - & - & NED 48M \\
\hline 10 & Sebenik et al (8) & 1998 & T4N0M0 & $\begin{array}{l}\text { Ch (VP16/CDDP), } \\
\text { Bp/Rt }\end{array}$ & - & - & NED 33M \\
\hline 11 & Samli et al (9) & 2000 & T4N1M0 & $\begin{array}{l}\text { Ch (FEC), Bt/R60Gy, } \\
\text { Ch (VP16/CDDP, FEC) }\end{array}$ & $\begin{array}{c}\text { Contralateral } \\
\text { subclavicular LN }\end{array}$ & Not described & AWD 9M \\
\hline 12 & Yamasaki et al (10) & 2000 & T2N0M0 & $\mathrm{Ch}(\mathrm{CMF})$ & - & - & NED $16 \mathrm{M}$ \\
\hline 13 & Shin et al (11) & 2000 & T1NXM0 & $\mathrm{Bp} / \mathrm{R}$ & - & - & NED 30M \\
\hline 14 & Shin et al (11) & 2000 & T1N0M0 & $\mathrm{Bp} / \mathrm{Ch} / \mathrm{R}$ & - & - & NED 27M \\
\hline 15 & Shin et al (11) & 2000 & $\mathrm{~T} 2 \mathrm{~N} 1 \mathrm{M} 0$ & $\mathrm{Bt} / \mathrm{Ch}$ & Liver & Not described & AWD $11 \mathrm{M}$ \\
\hline 16 & Shin et al (11) & 2000 & $\mathrm{~T} 2 \mathrm{~N} 1 \mathrm{M} 0$ & $\mathrm{Bp} / \mathrm{Ch} / \mathrm{R}$, tamoxifen & - & - & NED 35M \\
\hline 17 & Shin et al (11) & 2000 & T1N0M0 & $\mathrm{Bp} / \mathrm{R}$ & - & - & NED 25M \\
\hline 18 & Shin et al (11) & 2000 & $\mathrm{~T} 2 \mathrm{~N} 1 \mathrm{M} 0$ & $\mathrm{Bt} / \mathrm{Ch}$ & - & - & NED 10M \\
\hline 19 & Shin et al (11) & 2000 & $\mathrm{~T} 2 \mathrm{~N} 1 \mathrm{M} 0$ & $\mathrm{Ch} / \mathrm{Bt} / \mathrm{Ch}$, tamoxifen & Bone & Not described & AWD 32M \\
\hline 20 & Shin et al (11) & 2000 & T1N0M0 & $\mathrm{Bp} / \mathrm{Ch}$ & - & - & NED 10M \\
\hline 21 & Shin et al (11) & 2000 & $\mathrm{~T} 2 \mathrm{~N} 1 \mathrm{M} 0$ & $\mathrm{Bp} / \mathrm{Ch} / \mathrm{R}$ & - & - & NED 3M \\
\hline 22 & Shin et al (11) & 2000 & $\mathrm{~T} 1 \mathrm{~N} 1 \mathrm{M} 0$ & $\mathrm{Bt}$ & - & - & Not described \\
\hline 23 & $\begin{array}{l}\text { Salmo and } \\
\text { Connolly (12) }\end{array}$ & 2001 & T2N0M0 & $\begin{array}{l}\mathrm{Bp} / \mathrm{Ch}(\mathrm{VP} 16 / \mathrm{CDDP}), \\
\mathrm{R}\end{array}$ & - & - & NED 9M \\
\hline 24 & Hoang et al (13) & 2001 & T3NXMX & Not described & Not described & Not described & Not described \\
\hline 25 & Hoang et al (13) & 2001 & T3NXMX & Unknown & Unknown & Unknown & Not described \\
\hline 26 & Sridhar et al (14) & 2004 & T1N1M0 & $\begin{array}{l}\text { Bp/Ch (doxorubicin/ } \\
\text { CDDP), R }\end{array}$ & - & - & NED $18 \mathrm{M}$ \\
\hline 27 & $\begin{array}{l}\text { Jochems and } \\
\text { Tjalma (15) }\end{array}$ & 2004 & T2N0M0 & $\mathrm{Bt} /$ tamoxifen & - & - & NED 12M \\
\hline 28 & Yamamoto et al (16) & 2004 & T3N2M0 & Surgery & - & - & NED 34M \\
\hline
\end{tabular}


Table III. Continued.

\begin{tabular}{|c|c|c|c|c|c|c|c|}
\hline Case & Author/(Refs.) & Year & TNM & Primary treatment & Site of recurrence & Additional treatment & Prognosis \\
\hline 29 & Yamamoto et al (16) & 2004 & $\mathrm{~T} 2 \mathrm{~N} 1 \mathrm{M} 0$ & $\begin{array}{l}\text { Surgery/Ch }(\mathrm{CMF}) \text {, } \\
\text { tamoxifen, tremifene }\end{array}$ & - & - & NED 43M \\
\hline 30 & Bergman et al (17) & 2004 & $\mathrm{~T} 2 \mathrm{~N} 1 \mathrm{M} 0$ & $\mathrm{Bt}$ & Not described & Not described & Unknown \\
\hline 31 & Mariscal et al (18) & 2004 & T3N1M0 & $\mathrm{Ch}$ (CDDP/VP-16), Bp & - & - & NED 6M \\
\hline 32 & Bigotti et al (19) & 2004 & T4N1M0 & $\mathrm{Ch}, \mathrm{Bt}$ & Skin, CNS & Not described & DOD 14M \\
\hline 33 & Adegbola et al (20) & 2005 & T1N0M0 & $\begin{array}{l}\text { Bp/Ch (VP16/CDDP), } \\
\text { R }\end{array}$ & - & - & NED 48M \\
\hline 34 & Adegbola et al (20) & 2005 & T1N0M0 & $\begin{array}{l}\text { Bp, Ch (VP16/CDDP), } \\
\text { R }\end{array}$ & Unknown & Unknown & DOD 20M \\
\hline 35 & Adegbola et al (20) & 2005 & T1N1M0 & $\begin{array}{l}\text { Bp, Ch (VP16/CDDP), } \\
\text { R }\end{array}$ & Lung & Not described & AWD 6M \\
\hline 36 & Cabibi et al (21) & 2005 & T2N0M0 & $\mathrm{Bp}, \mathrm{Ch}, \mathrm{R}$ & - & - & Unknown \\
\hline 37 & Present study & - & T2NOM0 & $\begin{array}{l}\text { Bt/Ch (epirubicine, } \\
\text { cyclophosphamide) }\end{array}$ & Parasternal LN & R (50 Gy) & NED $60 \mathrm{M}$ \\
\hline
\end{tabular}

Bt, total mastectomy; Bp, partial mastectomy; Ch, chemotherapy; R, radiotherapy; VP-16, etoposide; CDV, cyclophosphamide, doxorubicin, vincristine; CMF, cyclophosphamide, methotrexate, 5-fluorouracil; FEC, 5-fluorouracil, epirubicine, cyclophosphamide; LN, lymph node; CNS, central nerve system; DOD, died of disease; DOC, died of other cause; NED, no evidence of disease; AWD, alive with disease; M, months.

respectively, $60-70 \%, 50-60 \%$ and $20-30 \%$ in the common phenotype of invasive ductal carcinoma $(22,23)$. Regarding the immunoreactivity of the neuroendocrine markers, the positive ratio of NSE, chromogranin and synaptophysin was $88 \%$ (30/34), 55\% (17/31), and 60\% (18/30), respectively. Diagnosis of these tumors was based on characteristic morphology, displayed by routine haematoxylin and eosin staining. It was found that the negative expression of neuroendocrine markers should not be used as an exclusion criterion (24). However, the presence of positive neuroendocrine markers strongly supports a positive diagnosis (11).

Due to their rarity, a standard course of therapy for primary small cell carcinoma of the breast has yet to be established (11). Although it seems logical that treatment of these tumors should be similar to that used for their pulmonary counterparts, most patients have been treated as standard cases of adenocarcinoma of the breast (Table III). The main treatment modalities are surgery, chemotherapy and irradiation. Regarding the chemotherapeutic regimens employed in the literature, standard chemotherapy for the treatment of adenocarcinoma of the breast, such as anthracycline (doxorubicin or epirubicine) combination regimen and CMF (cyclophosphamide, methotrexate, 5-fluorouracil), was performed in 6 cases. In 5 cases, tamoxifen was also used. CDDP and etoposide (VP-16), which are often used for pulmonary small cell carcinoma, were administered to 6 patients. Recent studies have suggested that irinotecan (CPT-11) is a key drug in the treatment of pulmonary small cell carcinoma. In fact, a combination of
CPT-11 and CDDP has been shown to be effective not only on pulmonary small cell carcinoma, but also on extrapulmonary small cell carcinoma such as esophageal small cell carcinoma (25). This suggests that the CPT-11 and CDDP combination may prove to be an effective treatment for small cell carcinoma of the breast.

In the literature, disease recurrence was reported in 10 cases. These recurrent tumors were located in the lymph node alone in 2 cases, the distant organs in 5 cases, and in the lymph nodes and distant organs in 3 cases. According to previous reports, treatment of recurrent sites was uniformly unsuccessful $(2,3,5,7)$. In the present report, the patient received a mastectomy and was administered postoperative adjuvant chemotherapy. In addition, radiotherapy was administered due to recurrence in the parasternal lymph nodes. As the recurrent site was localized, radiotherapy was effective for disease control and recurrence of the cancer has not been seen to date.

It has generally been thought that the prognosis for these tumors is equally as poor as it is for their counterparts in the lung $(1,3,7)$. However, recent reports $(10,20)$, our case included, suggest that the prognosis would be better if such tumors were detected earlier, and that a combination therapy including surgery, chemotherapy and radiation may improve survival time. It is also expected that an improved understanding of the clinical characteristics of the tumor will result in the development of new therapeutic modalities, which would presumably improve patient outcome. 


\section{Acknowledgments}

We thank Brian T. Quinn for his critical comments on the manuscript.

\section{References}

1. Ibrahim NB, Briggs JC and Corbishley CM: Extrapulmonary oat cell carcinoma. Cancer 54: 1645-1661, 1984.

2. Wade PM Jr, Mills SE, Read M, et al: Small cell neuroendocrine (oat cell) carcinoma of the breast. Cancer 52: 121-125, 1983.

3. Jundt G, Schulz A, Heitz PU, et al: Small cell neuroendocrine (oat cell) carcinoma of the male breast. Immunocytochemical and ultrastructural investigations. Virchows Arch A Pathol Anat Histopathol 404: 213-221, 1984.

4. Papotti M, Gherardi G, Eusebi V, et al: Primary oat cell (neuroendocrine) carcinoma of the breast. Report of four cases. Virchows Arch A Pathol Anat Histopathol 420: 103-108, 1992.

5. Francois A, Chatikhine VA, Chevallier B, et al: Neuroendocrine primary small cell carcinoma of the breast. Report of a case and review of the literature. Am J Clin Oncol 18: 133-138, 1995.

6. Chua RS, Torno RB and Vuletin JC: Fine needle aspiration cytology of small cell neuroendocrine carcinoma of the breast. A case report. Acta Cytol 41: 1341-1344, 1997.

7. Fukunaga $M$ and Ushigome S: Small cell (oat cell) carcinoma of the breast. Pathol Int 48: 744-748, 1998.

8. Sebenik M, Nair SG and Hamati HF: Primary small cell anaplastic carcinoma of the breast diagnosed by fine needle aspiration cytology: a case report. Acta Cytol 42: 1199-1203, 1998.

9. Samli B, Celik S, Evrensel T, et al: Primary neuroendocrine small cell carcinoma of the breast. Arch Pathol Lab Med 124: 296-298, 2000.

10. Yamasaki T, Shimazaki H, Aida S, et al: Primary small cell (oat cell) carcinoma of the breast: report of a case and review of the literature. Pathol Int 50: 914-918, 2000.

11. Shin SJ, De Lellis RA, Ying L, et al: Small cell carcinoma of the breast: a clinicopathologic and immunohistochemical study of nine patients. Am J Surg Pathol 24: 1231-1238, 2000.

12. Salmo EN and Connolly CE: Primary small cell carcinomas of the breast: report of a case and review of the literature. Histopathology 38: 277-278, 2001.

13. Hoang MP, Maitra A, Gazdar AF and Albores-Saavedra J: Primary mammary small-cell carcinoma: a molecular analysis of 2 cases. Hum Pathol 32: 753-757, 2001.
14. Sridhar P, Matey P and Aluwihare N: Primary carcinoma of breast with small-cell differentiation. Breast 13: 149-151, 2004.

15. Jochems L and Tjalma WA: Primary small cell neuroendocrine tumour of the breast. Eur J Obstet Gynecol Reprod Biol 115: 231-233, 2004

16. Yamamoto J, Ohshima K, Nabeshima K, et al: Comparative study of primary mammary small cell carcinoma, carcinoma with endocrine features and invasive ductal carcinoma. Oncol Rep 11: 825-831, 2004.

17. Bergman S, Hoda SA, Geisinger KR, et al: E-cadherin-negative primary small cell carcinoma of the breast. Report of a case and review of the literature. Am J Clin Pathol 121: 117-121, 2004.

18. Mariscal A, Balliu E, Diaz R, et al: Primary oat cell carcinoma of the breast: imaging features. AJR Am J Roentgenol 183: 1169-1171, 2004.

19. Bigotti G, Coli A, Butti A, et al: Primary small cell neuroendocrine carcinoma of the breast. J Exp Clin Cancer Res 23: 691-696, 2004.

20. Adegbola T, Connolly CE and Mortimer G: Small cell neuroendocrine carcinoma of the breast: a report of three cases and review of the literature. J Clin Pathol 58: 775-778, 2005.

21. Cabibi D, Cipolla C, Maria Florena A, et al: Solid variant of mammary 'adenoid cystic carcinoma with basaloid features' merging with 'small cell carcinoma'. Pathol Res Pract 201: 705-711, 2005.

22. Rhodes A, Jasani B, Balaton AJ, et al: Frequency of oestrogen and progesterone receptor positivity by immunohistochemical analysis in 7016 breast carcinomas: correlation with patient age, assay sensitivity, threshold value, and mammographic screening. J Clin Pathol 53: 688-696, 2000.

23. Press MF, Sauter G, Bernstein L, et al: Diagnostic evaluation of HER-2 as a molecular target: an assessment of accuracy and reproducibility of laboratory testing in large, prospective, randomized clinical trials. Clin Cancer Res 11: 6607, 2005.

24. Guinee DG Jr, Fishback NF, Koss MN, et al: The spectrum of immunohistochemical staining of small-cell lung carcinoma in specimens from transbronchial and open-lung biopsies. Am J Clin Pathol 102: 406-414, 1994.

25. Endo K, Kohnoe S, Toh Y, et al: A case of esophageal small cell carcinoma with multiple liver metastases responding to chemotherapy with irinotecan plus cisplatin. J Exp Clin Cancer Res 24: 647-650, 2005. 